delegation to the Conference are being dealt with by the British National Committee under the chairmanship of Mr. P. V. Hunter, at the offices of the British Electrical and Allied Industries Research Association. The official languages of the Conference will be English and French. Owing to the difficulties of accommodation, etc., intending delegates are requested to communicate with Mr. R. A. McMahon, Secretary, British National Committee, C.I.G.R.E., "Thorncroft Manor", Dorking Road, Leatherhead, as early as possible.

\section{British Council Conference Grants}

THe British Council has for some time had a small fund from which grants have been made in exceptional cases to permit foreign men of science (including agriculturists, engineers and medical men) to attend national or international conferences or meetings held in the United Kingdom. The principal grounds upon which such grants have been made are : $(a)$ that the application has been received from the body convening the conference or meeting; (b) that the Science Committee of the British Council has supported the application; (c) that the foreign visitor would be unable to attend without assistance. The grants cover subsistence or part-subsistence in the United Kingdom during the period of the conference or meeting. Fares to and from the United Kingdom are not included. No grants are made in respect of secretarial or other organising expenses, or for entertainment of delegates or hire of premises. Conveners of conferences or meetings to be held in the fiscal year 1948-49 are advised that it is necessary that applications for assistance to foreign visitors should be received not later than a fortnight from the publication of this notice. All applications will be considered together, and conveners will be notified of the results by the end of February. It is improb. able that more than a small proportion of applications can be met from the fund. Applications with full particulars (including reasons why financial support is considered necessary) should be addressed to the Administrator, Science Group, British Council, 3 Hanover Street, London, W.1.

\section{Coats Fellowships at Glasgow}

Messrs. J. AND P. Coats, Ltw., have provided funds for a research fellowship in chemistry or physics (excluding nuclear physics), tenable for two years, of the annual value of $£ 300$ and a supplement of $£ 50$ to cover research expenses. The Coats Fellow. ship will normally be awarded to a candidate with at least one year's experience in research work. It will be held in the University of Glasgow, but is open to graduates in science of any British university. The selection board will consist of the professors in the Departments of Chemistry and Natural Philosophy. A Coats Fellowship, similar in general conditions to that instituted at the University of Glasgow, is being offered to the Royal Technical College, Glasgow.

\section{Biography of Sir Joseph Barcroft}

Prof. K. J. Frankin, Department of Physiology, Medical College of St. Bartholomew's Hospital, Charterhouse Square, London, E.C.1, has been entrusted by Lady Barcroft and Prof. Henry Barcroft with the preparation of a biography of the late Sir Joseph Barcroft. He accordingly invites the cooperation of Sir Joseph's numerous friends and colleagues; he does not ask, at this stage, for specific information on particular aspects of Sir Joseph's life or work, but for general comments, such as mode of treatment, anecdotes, etc. Full acknowledgment will be made in any consequent publication, and it is assumed by Prof. Franklin that, should he be prevented from writing the biography, the material may be passed on to an alternative author chosen by Lady Barcroft and her son. Communications should be sent to Prof. Franklin at the address above by April 30 next.

\section{The Night Sky in February}

New moon occurs on Feb. 10d. 03h. 02m., U.T., and full moon on Feb. 24d. 17h. 16m. The following conjunctions with the moon take place: Feb. 5d. 06h., Jupiter $3^{\circ}$ N. ; Feb. 1ld. 06h., Mercury $8^{\circ}$ N. ; Feb. 13d. 12h., Venus $3^{\circ}$ N. ; Feb. 23d. 13 h. Saturn $4^{\circ} \mathrm{S} . ;$ Feb. 24d. 02h., Mars $0 \cdot 6^{\circ} \mathrm{S}$. During the first part of the month, Mercury is an evening star, setting at $18 \mathrm{~h} .20 \mathrm{~m}$. and $17 \mathrm{~h} .58 \mathrm{~m}$. on Feb. 1 and 14 respectively, and is in inferior conjunction on Feb. 20. At the end of the month it rises about three-quarters of an hour before the sun but will not be an easy object to observe. Venus, stellar magnitude about $-3 \cdot 5$, is conspicuous in the western sky and sets at $20 \mathrm{~h} ., 20 \mathrm{~h} .40 \mathrm{~m}$. and $21 \mathrm{~h} .30 \mathrm{~m}$. at the beginning, middle and end of the month respectively - several hours after sunset. Mars, in the constellation of Leo, rises in the early evening hours and can be seen throughout the night. Jupiter does not rise until the early morming hours-4h. $47 \mathrm{~m}$. and $3 \mathrm{~h} .18 \mathrm{~m}$. on Feb. 1 and 29 respectively; but as the planet does not attain an altitude greater than $16^{\circ}$ in the latitude of Greenwich, it is not very favourably placed for observation. Saturn, in the constellation of Leo, rises in the early evening hours and can be seen throughout most of the night. The planet is in opposition on Feb. 9. Occultations of stars brighter than magnitude 6 are as follows: Feb. 18d. 18h. 37-7m., v Taur. $(D)$; Feb. 18d. 19h. 05.3m., 72 Taur. (D) ; Feb. 20d. 00h. 49.9m., 125 Taur. $(D)$; Feb. 26d. 23h. 02.6m., $\gamma$ Virg. $m(D)$; Feb. 26d. 23h. $29 \cdot 7 \mathrm{~m} ., \gamma$ Virg. $m(R) ; D$ and $R$ refer to disappearance and reappearance, respectively, and the latitude and longitude of Greenwich are assumed. In addition to these occultations of stars, Mars is occulted by the moon on Feb. 24d. 01 h. 58.9 m., reappearing at 02h. $45 \cdot 4 \mathrm{~m}$.

\section{Announcements}

Sir Edward Mexilanby will deliver the Sir Frederick Gowland Hopkins Memorial Lecture of the Chemical Society at the Society's rooms on February 19 at 7.30 p.m.

A SERIES of five lectures on aspects of atomic energy has been arranged by the London Branch of the Atomic Scientists' Association. The lectures will be given in the lecture hall of the Royal Society of Arts, John Adam Street, Adelphi, W.C.2, at 7 p.m. on alternate Fridays, beginning February 6 . Tickets (2s. 6d. for one lecture; $10 s$. for the series) can be obtained from Dr. L. E. C. Hughes, 15 Avenue House, Allitsen Road, St. John's Wood, N.W.8.

AN exhibition of War Office teaching aids, under the title "The Better Chance", will be open during February 3-11 in the Imperial Institute, South Kensington, London, S.W.7. This is an augmented version of the exhibition held at Eltham Palace on September 15 (Nature, 160, 411; 1947). It is open to the public. 